\title{
And We cast upon his throne a mere body: A Historiographical Reading of Q. 38:34
}

\author{
M.O. Klar \\ SOAS, UNIVERSITY OF LONDON
}

The Islamic figure of Solomon is presented in four pericopes of the Qur'an. In Sura 21 (alAnbiy $\vec{a}^{3}$ ) reference is made to an episode where David and Solomon give judgement on a ravaged field, followed by details of David's and Solomon's special gifts - for the latter these were the wind that ran at his command, knowledge of everything and demons that worked for him. In Sura 27 ( $\mathrm{al}$-Naml) Solomon and David are mentioned with reference to the gift of knowledge God granted them both, and evidence of their gratitude; Solomon says to his men that he understands the speech of the birds and has been given of everything; then follows the story of the Valley of the Ants, and the famous episode between Solomon and the Queen of Sheba, which culminates in the Queen submitting to God.

The pericope in Sura $34\left(S a b a^{3}\right)$ again introduces Solomon through David and gives details of their special gifts, Solomon's being the wind, molten brass and mastery over the jinn. The concealment of Solomon's death from the jinn is referred to. Finally, in Sura $38(S \bar{a} d)$, again after mention of David, we are told that Solomon's horses were paraded before him, he missed the evening prayer and then either smote or stroked (depending on one's choice of interpretation) ${ }^{1}$ their shanks and necks, and, immediately prior to a list of God's gifts to him (the wind and the jinn), there is reference to God trying Solomon, casting a mere body on Solomon's throne, and to Solomon repenting: Q. 38:34, the focus of this paper, ${ }^{2}$

Certainly We tried Solomon, and We cast upon his throne a mere body; then he repented (wa-la-qad fatannā Sulaymān wa-alqaynā 'alā kursiyyihi jasadan thumma anāba)

Interpretations of this passage abound in the classical tafāsìr. Fakhr al-Dīn al-Rāzì cites both the storytellers and the ${ }^{c} u l a m \bar{a}^{\jmath}$ in his explanation of the verse, giving a total of five possible theories: that Solomon loses his throne to a demon as punishment for the idol-worship of one of his wives, or loses his throne after being tricked into handing his ring of sovereignty over to a group of demons; that the body of Solomon's baby is thrown down onto the throne after the prophet's misguided attempt to protect the child; that the prophet loses so much strength through illness, or that he was so overcome by fear, that he resembles a frail body on the throne. Rāzi only gives credence to the final three of these options. ${ }^{3}$ 
This paper does not however focus on the classical tafsì tradition; rather it utilises the alternative avenue of medieval historiographers and storytellers as a bridge to the various possible meanings of the Qur'anic text. The context upon which this study is based consists, therefore, of early and medieval works of Islamic historiography and collections of tales of the prophets: ${ }^{4}$ the early tenth century works of the Egyptian historian ${ }^{\mathrm{c}}$ Umāra b. Wathima ${ }^{5}$ and the well-known polymath Tabari, ${ }^{6}$ the eleventh century Tales of the Prophets by the Nīshāpūri Qur'an-commentator, Tha ${ }^{\mathrm{c}} \mathrm{labi \overline {i }}{ }^{7}$ the twelfth century folkloric collection of prophetic material attributed to $\mathrm{Kis}_{\overline{\mathrm{a}}}{ }^{\mathrm{p}}{ }^{8},{ }^{8}$ along with Ibn 'Asākir's History of Damascus of the same period, ${ }^{9}$ the thirteenth century world history by the private Mosuli scholar Ibn al-Athīr, conceived of as a continuation of Tabarī's work, ${ }^{10}$ and the fourteenth century historiographical work by the renowned traditionist Ibn Kathīr. ${ }^{11}$

For the purposes of this paper, these various works are viewed not as any particular stage in the development of a genre, but as variations on a (Qur'anic) theme. The exercise is not therefore a scientific attempt to attain the one true meaning, to unearth an Urtext, or to correct the so-called 'obscurities' (ibhāmāt), but a literary celebration of the multiplicity of meanings and significances to which such works can give rise. To paraphrase the nineteenth century Egyptian intellectual Muhammad 'Abduh (d. 1905), the Qur' an is not meant as a work of history, nor should its stories be taken as historical documents; rather, historic incidents are presented in order to convey lessons of admonition and exhortation, in order to serve ethical, spiritual and religious purposes. ${ }^{12}$ In a similar fashion, the importance of the story does not lie in the historical details but in the lesson of admonition deduced from it. Historiographers and storytellers provide us with an illustration of how such admonitions were perceived in medieval Islamic society. They also, as will become clear, provide a picture of Solomon that is consistent with the Qur'anic figure as a whole.

\section{Q. 38:34 in the Historiographical Tradition}

The basic understanding of the Q. 38:34 passage in the historiographical tradition would seem to be that Solomon did something wrong - failed a test set for him by God - and as a result was punished. The seven accounts investigated for the purposes of this study provide a wealth of different theories, and the action that originally led to God's testing of Solomon is variously interpreted (see Table 1).

The next part of the verse has meanwhile been explained as a reference to the casting down of the body of Solomon's infant son mentioned above, ${ }^{13}$ or the replacement of Solomon as monarch, either willingly by his wazir,${ }^{14}$ or unwillingly by the demon Sakhr, ${ }^{15}$ who magically assumes Solomon's form and through this acquires the signet ring in which Solomon's power resides, leaving the prophet himself to wander the streets unsupported and unrecognised (see Table 2). 


\begin{tabular}{|c|c|c|c|c|c|c|c|}
\hline $\begin{array}{l}\text { STATED REASONS } \\
\text { FOR SOLOMON'S } \\
\text { TRIAL }\end{array}$ & $\begin{array}{l}{ }^{c} \text { Umāra b. } \\
\text { Wathïma }\end{array}$ & Tabarī & Tha'labi & Kisāa $\overline{1}$ & $\begin{array}{c}\text { Ibn } \\
\text { cAsākir }\end{array}$ & $\begin{array}{l}\text { Ibn al- } \\
\text { Athir }\end{array}$ & $\begin{array}{l}\text { Ibn } \\
\text { Kathir }\end{array}$ \\
\hline $\begin{array}{l}\text { Solomon slaughters } \\
\text { horses at the parade- } \\
\text { ground }\end{array}$ & . & . & $\mathrm{x}$ & . & . & & . \\
\hline $\begin{array}{l}\text { Unspecified 'sin' } \\
\text { subsequent to marriage }\end{array}$ & . & . & $\mathrm{x}$ & . & . & . & . \\
\hline Solomon is 'tempted' & . & . & $\mathrm{x}$ & . & . & . & . \\
\hline $\begin{array}{l}\text { Worship of an idol } \\
\text { by Solomon's wife, } \\
\text { unbeknownst to the king }\end{array}$ & $x$ & $\mathrm{x}$ & $\mathrm{x}$ & $x$ & $x$ & $x$ & \\
\hline $\begin{array}{l}\text { Solomon marries an } \\
\text { unbeliever and sanctions } \\
\text { her worship of idols }\end{array}$ & . & . & $\mathrm{x}$ & . & $\mathrm{x}$ & . & . \\
\hline $\begin{array}{l}\text { Solomon marries an } \\
\text { unbeliever and crushes } \\
\text { a locust for the sake of } \\
\text { her god }\end{array}$ & . & . & . & . & $x$ & . & . \\
\hline $\begin{array}{l}\text { Solomon behaves } \\
\text { wrongly over settling } \\
\text { a dispute for the family } \\
\text { of one of his wives }\end{array}$ & . & $\mathrm{x}$ & $x$ & . & $\mathrm{x}$ & $x$ & . \\
\hline $\begin{array}{l}\text { Solomon is 'hidden' } \\
\text { from his people for } \\
\text { three days }\end{array}$ & . & . & $\mathrm{x}$ & . & $\mathrm{x}$ & . & . \\
\hline $\begin{array}{l}\text { Solomon gives baby } \\
\text { to clouds to prevent } \\
\text { child's death }\end{array}$ & $\mathrm{x}$ & . & $\mathrm{x}$ & . & $x$ & . & . \\
\hline $\begin{array}{l}\text { Solomon hands ring } \\
\text { over to demon in } \\
\text { exchange for knowledge } \\
\text { of stars }\end{array}$ & $\mathrm{x}$ & . & . & . & $\mathrm{x}$ & . & . \\
\hline $\begin{array}{l}\text { Solomon simply drops } \\
\text { the ring by accident }\end{array}$ & & . & . & . & $x$ & . & - \\
\hline
\end{tabular}

Table 1. Stated reasons for Solomon's trial 


\begin{tabular}{|c|c|c|c|c|c|c|c|}
\hline $\begin{array}{l}\text { STATED EXPLANATIONS } \\
\text { FOR A MERE BODY }\end{array}$ & $\begin{array}{l}{ }^{c} \text { Umāra b. } \\
\text { Wathīma }\end{array}$ & Tabarī & Tha ${ }^{c}$ labì & $\operatorname{Kis}^{\top}{ }^{\top} \overline{1}$ & $\begin{array}{c}\text { Ibn } \\
\text { 'Asākir }\end{array}$ & $\begin{array}{l}\text { Ibn al- } \\
\text { Athīr }\end{array}$ & $\begin{array}{c}\text { Ibn } \\
\text { Kathir }\end{array}$ \\
\hline $\begin{array}{l}\text { Solomon's son is cast } \\
\text { down onto throne }\end{array}$ & $x$ & . & $x$ & & $x$ & • & . \\
\hline $\begin{array}{l}\text { Solomon is replaced } \\
\text { by his wazir }\end{array}$ & . & . & $x$ & . & . & . & . \\
\hline $\begin{array}{l}\text { Solomon is replaced by } \\
\text { Sakhr the demon }\end{array}$ & $x$ & $\mathrm{x}$ & $\mathrm{x}$ & $\mathrm{x}$ & $x$ & $\mathrm{x}$ & . \\
\hline
\end{tabular}

Table 2. Stated explanations for a mere body

These three explanations provide a focus for the historiographical material dealing with Q. 38:34, and are the only instances where the entire verse is given a narrative exploration as a cohesive unit. That is to say that, although many reasons are given for Solomon's trial, it is rare that the narrative does not focus solely on explaining laqad fatannā Sulaymān rather than pursuing the implications of the verse as a whole: it is only where the narrative concentrates on wa-alqayna cala kursiyyihi jasadan that the implications of the entire verse are raised and explored, from Solomon's temptation through to the day his repentance is accepted.

Let us therefore investigate each of these explanations, in turn, in the broader context of the historiographical Solomon tradition.

a) The Death of Solomon's Son

The first explanation for the verse, the story of Solomon's infant son, is a widespread one, which exists in a variety of guises. The anecdote referred to above is the version given by the ninth century historian ' ${ }^{c}$ Umāra $b$. Wathīma, the eleventh century Nīshāpūrī Tha ${ }^{c}$ labī, and the twelfth century Syrian Ibn ${ }^{c}$ Asākir. In ${ }^{c}$ Umāra b. Wathìma and Ibn 'Asākir, Solomon's only son is born with a disability and the prophet fears that the boy will die. Then, in Tha ${ }^{c}$ labī, we are told that he hears of a jinni plot to kill the child or deprive him of his senses (the demons fear that if Solomon has a male successor he will inherit Solomon's mastery over them and they will live in bondage forever); in 'Umāra b. Wathīma and Ibn ' ${ }^{c}$ Asākir's accounts the story is that the child refuses to accept either the human or the jinni wet-nurse offered to him: in both accounts the result is that the baby is carried up into the clouds by the wind, at Solomon's command, and nourished on rainwater, one would have thought safe from harm. The child, however, dies (in ' Umāra b. Wathīma and Ibn ' Asākir God orders the Angel of Death to take the baby's soul) and the empty body is then thrown down from the sky onto Solomon's throne, hence the Qur'anic verse, Certainly We tried Solomon, and We cast upon his throne a mere body; then he repented. ${ }^{16}$ 
Ibn ${ }^{c}$ Asākir in addition gives another variant of the damaged child episode, one that is also provided by the ninth century historian ${ }^{c}$ Umāra $b$. Wathima and the fourteenth century Sunnī traditionist Ibn Kathīr. ${ }^{17}$ In this account, Solomon boasts that he can impregnate all one hundred women of his harem with strong fighting men, in a single night. However, he neglects to add the proviso 'God willing' (in shä' Allāh), so impregnates just one of his wives, and with a child that is 'half a person' (shiqq/nisf insän). A prophetic hadith is cited in which Muhammad comments that, had Solomon only said in shä $\bar{a}^{\jmath}$ Allāh, God would have fulfilled His prophet's boast. It is clear therefore that the message of the anecdote is the same as that of the previous account: it is best to put your faith in God rather than in your own powers, a familiar Qur'anic theme ${ }^{18}$ and also one that is exemplified in attitudes to the workings of the devil Iblis encourages man to exaggerate his own powers and to imagine himself the omnipotent god, thus Awn: ${ }^{19}$

[The devil is] a master at embellishing the deeds of man, giving them false confidence in their own powers

Tha ${ }^{c}$ labì gives us a suggested reason for the order to take the child's soul - that God censured Solomon for his fear of demons (fa- ${ }^{c}$ ätabahu'llāh li-takhawwufihi min alshayattīn). ${ }^{20}$ If, however, we compare this anecdote to the story (given within Tha ${ }^{c}$ labī's Solomon narrative) of the boy in the glass dome, whose mother's dying wish that he be protected by God from Iblis and his armies is granted (the boy subsequently lives in a glass dome in the middle of the sea, and is fed by a white bird that appears nightly), ${ }^{21}$ the lesson implicit in the Solomon story crystallises in a subtly different fashion. There the woman asks God for protection from Iblis and her request is granted; here Solomon himself tries to protect his child from Iblis and he is rebuked. Therefore the lesson that emerges from the story as a whole is not specifically that fear of demons is to be avoided, but that one should turn to God with this fear. ${ }^{22}$ The fact that, according to some, Solomon is only given mastery over the jinn after the body on the throne incident, ${ }^{23}$ is not insignificant in our understanding of the ultimate rights and wrongs of this issue.

\section{b) Solomon is Replaced by his Wazir}

The second suggested explanation for the 'body' on the throne is that Solomon's talismanic ring of power loosens on his finger when he is tempted (uftutina), and keeps falling off, causing his wazi $r^{24}$ to comment 'you are tempted by your sin' (innaka maftūn bi-dhanbika). So, at the latter's suggestion, Solomon hands the ring of sovereignty over to his wazir who will man the throne for fourteen days while the prophet himself 'flees to his Lord' (farra Sulaymān häriban ilā rabbihi). He then returns to the palace, restores the ring to his finger, and resumes his kingly duties. ${ }^{25}$ 
Tha ${ }^{c}$ labi is the only one of my sources to allude to this narrative, and it is clearly a very ambiguous one in many of its details. A context for the passage is however arguably provided in Tha ${ }^{c}$ labì's tafsir. There we are told that, prior to these same events, Solomon was 'tested through taking the statue into his home' (uftutina biakhdh al-timthāl fi baytihi). ${ }^{26}$ Rāzĩ similarly informs us that Solomon's ring loosens on his finger when his wife starts worshipping the idol and he is subject to temptations (uftutina) ${ }^{27}$ The story of the statue and the idol-worshipping wife is a familiar one to us, as it occurs in five of our six sources (although, as will become clear in section (c) below, the resolution of the tale differs from the anecdote cited above). During his conquests, Solomon comes across a beautiful princess with whom he falls desperately in love (Tabarī tells us 'ahabbaha hubban lam yuhibbahu shay'an min nisā̄ihi wa-waqa'at nafsuhu 'alayh $\bar{a}$ '; Tha' labī 'ahabbahā hubban shadīdan lam yuhibbahu ahadan min nisā ihi'; while ' Umāra b. Wathīma and Ibn ${ }^{\mathrm{c}}$ Asākir comment 'iștafāhā li-nafsihi wa-kāna yajidu bihā mā lā yajidu bi-ahadin wa-kāna yu'thiruhā ${ }^{c}$ ala nis $\left.\bar{a}^{\top} i h i^{\prime}\right) .{ }^{28}$ She converts to Islam ${ }^{29}$ and becomes the prophet's wife. Upon returning to his palace, she cannot contain her grief for her dead father. Solomon is distressed by her tears (thus Tabarī, 'wa-huwa yashuqqu 'alayhi min dhälika'), ${ }^{30}$ and persuaded to order that a statue be made of her parent so that her grief might be assuaged. She secretly begins to worship it. ${ }^{31}$

The loss of sovereignty in return for this incident makes it clear that the prophet was held to have been at fault: ${ }^{32}$ the question is whether Solomon was at fault for the physical act of allowing that a statue be made, ${ }^{33}$ or for his misguided indulgence of his wife's desire. In the narrative of 'Umāra b. Wathīma, Tabarī and Ibn al-Athīr, the prophet's wazir tells him that these events took place for love of a woman $(f i$ hawa $i m r \bar{a} a):{ }^{34}$ the suggestion seems to be that Solomon's motivation for carrying out these actions is implicated in his trial. More significant, however, is an almost parallel episode cited in Ibn ${ }^{\mathrm{c}}$ Asākir. There Solomon asks a woman who pleases him to convert to Islam but she refuses. As he is greatly in love with her (ahabbaha hubban shadīdan) and cannot resist her (lā yașbiru ${ }^{c} a n h \bar{a}$ ), he marries her despite the fact that she is an idol worshipper, in the hope that his kindness towards her will persuade her to change her mind (wa-kāna yarfuqu bihā wa-yatawaddaduhā rajă an an tuslima). She then threatens suicide if Solomon will not concede to sacrifice something to her idol. After much protesting, Solomon eventually concedes to a locust (jarāda: it is worth pointing out that Jarāda also happens to be the given name of the idol-worshipping wife in most versions of the tale). At the point he cuts off the locust's head, his sovereignty disappears. God rebukes Solomon at length for his actions, and Solomon spends forty days begging God's pardon before he finds the ring in the belly of the fish and sovereignty returns to him. ${ }^{35}$

Both of these anecdotes, regardless of their plausibility, authenticity, or narrative development, can therefore be read as alluding to the same perceived feature of the 
prophet's sovereignty; that it is compromised when he falls in love. The confusion between the name of the idol-worshipping wife and a real locust sacrificed to gods other than God only adds to our impression that it is Solomon's feelings themselves that are at stake here. A tendency for Solomon to fall in love is apparent throughout the Solomon narrative: as well as his 'great passion' for the foreign princess and the suicide-threatener, Solomon is described, in Tha ${ }^{c}$ labī and Ibn al-Athīr, as having very similar feelings for the Queen of Sheba (ahabbahā hubban shadidan). ${ }^{36}$ This friction between sovereignty and humanity, and the ensuing lack of control when a balance is not adequately maintained, is an important element in the historiographical portrayal of the Solomon story. Moreover the contrast with other prophetic figures epitomised in their dealings with women - Joseph and Zulaikha, ${ }^{37}$ David and Bathsheba ${ }^{38}$ - is marked. In the case of Solomon, the bulk of his difficulties arise not in achieving, or resisting, the formalisation of a relationship, but in negotiating the compromises of his married life.

\section{c) Solomon is replaced by Șakhr the Demon}

By far the most commonly cited explanation given by Islamic historiographers for the Qur'anic verse is that Solomon is punished on account of his wife's practice of idolworship in his palace by the loss of his throne to a demon named Sakhr. After Solomon's wazìr discovers what has been going on in Solomon's household and informs the prophet, Solomon promptly smashes the idol, punishes the errant wife, and goes into the desert to repent of his mistake. An unspecified time after this, he goes into the bathroom and, as is his normal custom, hands the ring of power over to one of his maidservants, Amina, ${ }^{39}$ for safekeeping while he is in a state of impurity. The demon Șakhr then appears in Solomon's form, takes the ring from the unsuspecting maidservant, and sits on the king's throne. When Solomon comes out of the bathroom, either Amina does not recognise him as he too has turned into someone else, or she is confused by the appearance of a second Solomon. Either way, Solomon realises that 'his sin has caught up with him' (fa- ${ }^{c}$ arafa Sulaymān anna khațī atahu qad adrakathu $)^{40}$ and flees the palace. After forty days he acquires a fish and, when he slices its belly open to clean it, finds his ring of power. He puts it on, his sovereignty is returned to him, and the demon subsequently flees the palace. Solomon then orders that the demon be captured and he is trapped in a stone jar and thrown into the sea. $^{41}$

That Solomon is bodily replaced by a demon known as Șakhr can again be read as dealing with issues of control: but whereas the first explanation we discussed dealt with Solomon's attempts to control the natural world, and the second with Solomon's attempts to control himself (it is because Solomon cannot stop himself from falling in love that he finds himself in difficulties and his wazir is required to take the throne for 
a time), here we have a total and complete loss of control - Solomon is involuntarily 'replaced' by someone who looks just like him, while the 'real' him no longer inhabits the familiar external form; thus the prophet effectively loses all control over his perceived actions, and is powerless to stop the process as those to whom he protests disbelieve that he is in fact Solomon. The loss of kingdom is a familiar motif in prophetic tales - Solomon's father David after all loses his throne following his involvement with Bathsheba; ${ }^{42}$ the biographies of the prophets, like Greek tragedy, often work on a principle of reversal ('alternating states of anger and serenity', 'alternating periods of exile and kingship' ' ${ }^{43}$ - but the loss of one's external form to another is unusual. This episode is moreover interesting if one looks at it not as a literal description of events, but as a logical psychological extension of the fear of demons exhibited in explanation (a), where Solomon gives his child over to the clouds for safe-keeping.

This version of the tale given above is the standard version and is given in all of my sources apart from Ibn Kathīr's Qiṣas al-anbiya $\bar{a}^{\text {}}$. This scholar notably makes reference to, then emphatically distances himself from, such accounts, explaining that most of these stories are just legends, and some of them are downright harmful: he refers the reader to his Tafsi $r$, where he gives several versions of the tale. ${ }^{44}$ The modern editor of Ibn al-Athīr, Abū'l-Fidā ${ }^{\prime}$ 'Abd Allāh al-Qāḍī, gives some indication of why these accounts may have been disapproved of in a footnote to Ibn al-Athī's text. ${ }^{45} \mathrm{He}$ states that, if demons could impersonate prophets, how could we then rely on their law, their Shari ${ }^{-c} a$ ? And how could anyone think that God would allow a demon to have access to a prophet's wives? What prophet would have his sovereignty and prophethood residing in a seal ring? ${ }^{46}$ And why would God change His prophet's outer form? These concerns are all valid ones - the idea that a person could be powerless to prevent his life from being taken over by an outsider is a disturbing one, especially if that person is a figure of religious, moral and legislative authority and it is very easy to see why Ibn Kathīr and ' Abd Allāh al-Qādī had such a problem with it. Fakhr al-Dīn al-Rāzī too addresses this issue in a comprehensive fashion in his Tafsir, protesting that: 1) demons cannot take the form of prophets; 2) demons cannot even behave in this fashion towards mankind; 3) God would not give a demon mastery over Solomon's wives; and 4) it would be unthinkable to suggest that Solomon sanctioned his wife's behaviour, and Solomon would not be blamed for his wife's worship of idols unbeknownst to him. ${ }^{47}$

However to dismiss the tales as an irrelevance on this account is to belie the function implicit in their very pervasiveness. The concerns of ${ }^{\mathrm{c}}$ Abd Allāh al-Qādī and Fakhr al-Dīn al-Rāzī are moreover to some extent allayed within the Șakhr story itself. We are told in all the sources (apart of course from Ibn Kathīr who does not cite the story in his history; this detail is however given in his $T a f s i r)^{48}$ that the Israelites became suspicious when the person they thought was Solomon started giving uncharacteris- 
tic judgements. ${ }^{49}$ They then turned to Solomon's wives to ask whether they had perceived any difference in the man, and they start to cry, explaining that he, in some accounts only, ${ }^{50}$ desires them when they are menstruating and so they naturally, in accordance with Islamic law, turn him away. ${ }^{51}$ (Tabarī and Tha ${ }^{\mathfrak{c}}$ labī also incidentally point out that the impostor does not wash himself of ritual impurity which seems slightly ironic as it was the very removing of the ring of power by Solomon in order to wash himself of ritual impurity that gives Sakhr the opportunity to steal the ring in the first place. $)^{52}$ In some accounts, the demon then senses the people's suspicions and flies away, in others he leaves when the people assemble before him and recite the Torah. ${ }^{53}$ Thus although we cannot rely on the law of demons who impersonate prophets, we can perceive when things are not right and easily make the demon run away; and although the demon theoretically had access to the prophet's wives, his desires are so unusual for a Muslim male that the wives do not concede to them and no access is granted ${ }^{54}$ Although this is not expressly mentioned within the context of the historiographical Solomon material, we are told in a hadith that God prevented the devil from ever appearing in Muhammad's form in our dreams: if you dream about Muhammad you can be sure that anything he says to you is reliable and authentic. ${ }^{55}$ This can therefore be read both as an oblique acknowledgement of, and as a limitation of, the plausibility and applicability of the Solomon story. An acknowledgement inasmuch as it confirms the possibility of a demon appearing in a prophet's form; a limitation insofar as it places restrictions on the extent to which demons can do this. ${ }^{56}$

It seems, therefore, that there was no permanent harm done while Solomon was away. Solomon may well have suffered discomfort: ${ }^{c}$ Umāra and Ibn ${ }^{c}$ Asākir tell us he fled for his life frightened that the demon was going to kill him, ${ }^{57}$ all agree that he fled. Nobody recognised him and when he told them he was Solomon, king and prophet, they deny him, and, at worst, hit him. ${ }^{58}$ In most accounts he goes hungry and has to rely on charity. But then he finds the ring and everything bows down to him and apologises for what went before. In some versions of the tale Solomon barely suffers this period of hardship but is taken in by a charitable family who marry him to their daughter, one of the most beautiful women of the age. ${ }^{59}$ And meanwhile the community, who might have been expected to suffer hideous consequences when under the rule of a demon masquerading as their king and prophet, seem to manage surprisingly well. But surely the message of the tale cannot be don't worry about surrendering yourself to your inner demon, he's really quite harmless? Is the community, or is Solomon our focus in this tale?

Is it even fair to say that Sakhr is Solomon's inner demon? Peter Awn, in his study of the psychology of the Satan figure in Islamic mysticism, describes how the original struggle between Adam and Satan, Ibliss, is relived in every man and woman's conflict with the Satanic forces in creation. He comments that: ${ }^{60}$ 
It is a consummate irony that the jealousy and hate that have characterized the relationship between Iblis and Adam only serve to link them together for eternity. They will never be rid of each other; one's fate is intimately involved with the other's. Their conflict will be played out time and time again in the lives of their descendants, "enemies one to the other" (Qur'an 2:36).

It is also interesting to note the parallels between the description of Iblis' fall from grace and Solomon's temporary loss of power and status: both figures undergo an external and internal transformation. Thus Iblis is stripped of all power, his form changes from that of an angel to that of a devil, his name changes, and the door of repentance is closed to him; ${ }^{61}$ Solomon is stripped of all power, his form changes from that of the familiar prophet to either that of a devil or to something unnamed but unrecognisable, when he tries to tell people his name they deny and beat him, and the door of repentance is closed to him for forty days. This does not in any way suggest the vilification of Solomon; rather it serves to muddy the boundaries between Solomon and Iblīs/Șakhr.

So who is Șakhr the demon? What can we deduce about Șakhr's personality and narrative purpose in the Solomon story? He weaves in and out of the narrative, in some accounts appearing when Solomon first subjugates the jinn to his command, ${ }^{62}$ in most accounts being summoned in order to solve the problem of how to noiselessly cut stone, ${ }^{63}$ sometimes surfacing in order to prompt Solomon's wife into the worship of idols ${ }^{64}$ and often being used in order to fashion these idols, ${ }^{65}$ sometimes being summoned to cast a spell making the chore of milling easy, ${ }^{66}$ and almost universally appearing in the narrative to trick his way into Solomon's palace and onto his throne. ${ }^{67}$ In some accounts Șakhr makes Solomon's throne, ${ }^{68}$ in others he is introduced as Master of the $\mathrm{Sea}^{69}$ (the sea is a constant motif in many versions of the tale). In Ibn 'Asākir we are told that Solomon initially spares Șakhr's life because of reports of the demon's kindness (rifq) and good deeds $\left(\operatorname{san} \bar{a}^{\top} i^{c}\right) \cdot{ }^{70}$ Indeed, the folkloric Kisā ${ }^{\supset} \overline{1}$, the ninth century ${ }^{c}$ Umāra ibn Wathīma and the Syrian Ibn ${ }^{c}$ Asākir all present the demon as Solomon's friend: 'Umāra and Ibn 'Asākir describe how the prophet honoured the demon (akramahu), brought him close (qarrabahu), sought his advice (shāwarahu), and tell how the pair take evening strolls together on the sea shore; ${ }^{71}$ Kisā̄i speaks of a palace by the sea which the prophet builds for himself and the demon to live in, sideby-side. ${ }^{72}$ Sunfi texts warn of the dangers of allowing one's companion demon too close; they also stress the heightened risk from devilish plots at evening time. ${ }^{73}$

The recurring sea motif is worthy of mention. Not only is Șakhr the Master of the Sea, who lives with Solomon in a palace by the sea, takes walks with the prophet along the sea coast, drops the ring of power into the sea, and eventually is imprisoned in a stone 


\begin{tabular}{|c|c|c|c|c|c|c|c|}
\hline ȘAKHR PERICOPES & $\begin{array}{l}\text { 'Umāra b. } \\
\text { Wathīma }\end{array}$ & Tabarī & Tha ${ }^{c}$ labi & Kisāa $\overline{1}$ & $\begin{array}{c}\text { Ibn } \\
{ }^{c} \text { Asākir }\end{array}$ & $\begin{array}{l}\text { Ibn al- } \\
\text { Athir }\end{array}$ & $\begin{array}{l}\text { Ibn } \\
\text { Kathìr }\end{array}$ \\
\hline Șakhr is master of the sea. &. & $\mathrm{x}$ & $\mathrm{x}$ & . &. &. & . \\
\hline $\begin{array}{l}\text { Sakhr flees to avoid } \\
\text { enslavement to Solomon. }\end{array}$ & $x$ & . & . & $\mathrm{x}$ & $x$ & . & . \\
\hline $\begin{array}{l}\text { Șakhr captured by } \\
\text { demons ... }\end{array}$ & $\mathrm{x}$ & . & . & $\mathrm{x}$ & $\mathrm{x}$ & . & . \\
\hline $\begin{array}{l}\text {... or Sakhr summoned by } \\
\text { seal ring to help Solomon. }\end{array}$ & . & . & $\mathrm{x}$ & . & . & . & . \\
\hline $\begin{array}{l}\text { Sakhr laughs at mankind's } \\
\text { claims to prescience. }\end{array}$ & · & . & $\mathrm{x}$ & $\mathrm{x}$ & . & . & . \\
\hline $\begin{array}{l}\text { Sakhr solves problem of } \\
\text { stone-cutting. }\end{array}$ & $\mathrm{x}$ & . & $\mathrm{x}$ & $\mathrm{x}$ & $(x)^{74}$ & . & . \\
\hline $\begin{array}{l}\text { Sakhr solves problem of } \\
\text { milling. }\end{array}$ & $\mathrm{x}$ & . & . & . & $\mathrm{x}$ & . & . \\
\hline $\begin{array}{l}\text { Sakhr makes Solomon's } \\
\text { throne. }\end{array}$ & . & . & $\mathrm{x}$ & $\mathrm{x}$ & . & . & . \\
\hline $\begin{array}{l}\text { Sakhr tricks Solomon's } \\
\text { wife into asking for statue } \\
\text { and ... }\end{array}$ & $\mathrm{x}$ & . & . & . & $\mathrm{x}$ & . & . \\
\hline $\begin{array}{l}\text {.. Solomon orders Sakhr } \\
\text { to make statue for his wife. }\end{array}$ & $\mathrm{x}$ & . & . & $\mathrm{x}$ & $\mathrm{x}$ & . & . \\
\hline $\begin{array}{l}\text { Sakhr builds a palace by } \\
\text { the sea and lives there } \\
\text { with Solomon. }\end{array}$ & . & . & . & $\mathrm{x}$ & . & . & · \\
\hline $\begin{array}{l}\text { Sakhr takes Solomon's } \\
\text { form and steals the ring. }\end{array}$ & $\mathrm{x}$ & $\mathrm{x}$ & $\mathrm{x}$ & $\mathrm{x}$ & $\mathrm{x}$ & $\mathrm{x}$ & . \\
\hline $\begin{array}{l}\text { Sakhr gives faulty } \\
\text { judgements and ... }\end{array}$ & $\mathrm{x}$ & $\mathrm{X}$ & $\mathrm{x}$ & . & $\mathrm{x}$ & $\mathrm{x}$ & . \\
\hline $\begin{array}{l}\ldots \text { desires menstruating } \\
\text { women and ... }\end{array}$ & $\mathrm{x}$ & $\mathrm{x}$ & $\mathrm{x}$ & . & $x$ & . & . \\
\hline $\begin{array}{l}\text {.. Sakhr does not remove } \\
\text { ritual impurity. }\end{array}$ & . & $\mathrm{x}$ & $\mathrm{x}$ & . & . & . & . \\
\hline $\begin{array}{l}\text { Șakhr hides magic formula } \\
\text { beneath the throne. }\end{array}$ & $\mathrm{x}$ & . & . & $x$ & $\mathrm{x}$ & . & . \\
\hline $\begin{array}{l}\text { Sakhr flees when the } \\
\text { Torah is read to him ... }\end{array}$ & . & $\mathrm{x}$ & $\mathrm{x}$ & . & . & $\mathrm{x}$ & . \\
\hline $\begin{array}{l}\text {... or Sakhr flees when he } \\
\text { sees Solomon ... }\end{array}$ & . & . & . & $x$ & . & . & . \\
\hline $\begin{array}{l}\text {... or Șakhr flees of own } \\
\text { accord. }\end{array}$ & $x$ & $\mathrm{x}$ & $x$ & . & $x$ & $\mathrm{x}$ & . \\
\hline $\begin{array}{l}\text { Sakhr is humbled by } \\
\text { sight of Solomon's ring } \\
\text { and... }\end{array}$ & $x$ & . & . & $x$ & $\mathrm{x}$ & . & . \\
\hline $\begin{array}{l}\text {... Sakhr is imprisoned } \\
\text { and cast into the sea. }\end{array}$ & $x$ & $\mathrm{x}$ & $x$ & $x$ & $x$ & $\mathrm{X}$ & . \\
\hline
\end{tabular}

Table 3. Sakhr pericopes 
jar at the bottom of the sea, ${ }^{75}$ but in Tha ${ }^{c}$ labi Solomon sends divers to discover the depth of the sea, ${ }^{76}$ and in both Tha ${ }^{c}$ labi and Kisā ${ }^{\top} \overline{1}$ he asks God that he be allowed to attempt to feed all the creatures of the sea for one day, rather than God taking His usual responsibility for this task. ${ }^{77}$ Needless to say, Solomon fails in both these endeavours. Can the sea, whose secrets Solomon wishes to understand, which Solomon wishes to control and out of whose depths his demonic other first appears and is then re-imprisoned, be seen as symbolic of the prophet's unconscious? Jung writes that 'the sea is the favourite symbol of the unconscious' ${ }^{78}$ On a similar note, Wendy Doniger O'Flaherty comments that: ${ }^{79}$

The fish that swallows the ring of the cast-off child (or Jonah or Pinocchio), only to reveal it again years later, becomes a symbol of memory, of the persistence of the past, perhaps of the unconscious. This symbolism is widespread, perhaps indeed archetypal.

It is worth remarking that while Sakhr always takes Solomon's form, there are varying accounts for whether the prophet then also keeps his own form, ${ }^{80}$ takes another unspecified form, ${ }^{81}$ or turns into the demon in a neat reversal of identities. ${ }^{82}$ Șakhr also takes, in several accounts, the form of the brother of Solomon's distraught wife, ${ }^{83}$ of whom we are told that he loved her more than anyone he had ever loved in the past, but that this was not enough to prevent her sadness at the death of her family. It is to stop her sadness that Solomon asks Sakhr to fashion for her the statue which leads to the episode of idol-worship. Is it significant that it is Sakhr whom Solomon asks to do this?

It quickly becomes apparent that it would be a misleading and inaccurate oversimplification to dismiss the situation as any static confrontation between good and evil (such monochrome depictions of subtle moral and ethical interplays are hardly typical of material of this type). It is interesting to compare the situation with theories of mimesis, where what was formerly the model becomes an obstacle and a rival, and, as the crisis deepens, it becomes such that no difference between the rivals is perceptible to an outsider. To cite Rene Girard, 'from within the system, only differences are perceived; from without, the antagonists all seem alike. From inside, sameness is not visible; from outside, difference cannot be seen. ${ }^{84}$ It is also interesting however to look to theories of psychoanalysis, to Bettelheim, who sees stories which feature twins or brothers as representing contrasting, but vital, tendencies within a single personality. ${ }^{85}$ Thus Bettelheim: ${ }^{86}$

two brothers stand for inner psychic processes which must all be functioning together for us to exist.

This ties in with the blurring of the boundaries between Solomon and Sakhr suggested above. 
So can we still argue that on a certain level the story of Solomon is one of resisting the devil? Indeed we can. Any ambiguity in the way the borders between prophet and demon are drawn does not make Sakhr any less a force to be combated. Indeed the mystical philosophy of renouncing worldly goods, being wary of indulgence, avoiding the temptation of women, is expressed time and time again throughout the various versions of the tale. In several anecdotes it is suggested that all the wealth possessed by Solomon is meaningless, that he would exchange it all for a single statement in praise of God. Knappert writes that: ${ }^{87}$

The relationships of Man to God and to Woman are foremost in the histories of the prophets. Third comes the relationship of Man to this earth, in particular to Desire of Possession.

Thus Tha ${ }^{c}$ labī, where Solomon tells a ploughman who marvels at his gifts that a statement of praise accepted by God from the ploughman is worth more than what was given to the family of David (inna tasbịha wähida yaqbaluhā'llāh minka khayrun mimmā ūtā $\bar{a} l D \bar{a} w u d) .{ }^{88} \mathrm{He}$ slaughters his beloved horses after they interfere with his prayer. ${ }^{89}$ His mother warns him against sleeping throughout the night, explaining that those who do so will find themselves very poor on Judgement Day: Ibn Kathī tells us that excessive sleep inhibits worship (fa-inna kathrata'l-nawm bi'l-layl tada' $u^{\prime} l$ $\left.{ }^{c} a b d\right) .{ }^{90}$ In Ibn Asākir, the prophet informs his father that a wise man (al- $\left.{ }^{c} \bar{a} q i l\right)$ does not indulge in gaiety or let himself be overwhelmed by his passions (la yastakhiffuhu $u^{\top}$ farah wa-lä yaghlibuhu hawāhu). ${ }^{91}$ The Solomon biography is moreover a tale dominated by women - the interplay with the Queen of Sheba, ${ }^{92}$ with the idolworshipping wife; ${ }^{93}$ the enclosed narrative that deals with fated love $;{ }^{94}$ women are given a voice in the derunciation of Sakhr the demon, ${ }^{95}$ and in the giving and withholding of the Ring of Power; ${ }^{96}$ even the tufted ant with whom Solomon has a lengthy interchange is female, ${ }^{97}$ and it is frequently because of his desire for and tenderness towards women that Solomon goes astray.

So we can definitely say that the ideal of battling one's inner demon, of resisting the temptations both of the flesh and of the heart, is exemplified throughout the story. We can also however say that, by muddying the physical boundaries between demon and prophet, by its use of the motif of the sea, by making Sakhr and Solomon friends as well as enemies, the story shows how much a part of you that demon is. This presumably is why the story has the power to unsettle and upset.

\section{Conclusions}

Deeper meaning can be perceived within the Q. 38:34 anecdotes on various levels: the incident of the body of Solomon's child being cast down onto his throne explores aspects of Solomon's mastery over nature, and reinforces our perception of the 
supposed boundaries to this power; the narrative where Solomon is replaced by his wazir alludes to difficulties experienced by the prophet in negotiating a compromise between romantic and sovereign/religious life; the Șakhr narrative suggests issues of form and identity, as well as raising the question of what damage a demon has the capacity to cause and identifying our best tools in limiting that damage. All three explanations moreover allude to aspects of the Solomon persona other than those expressed within Q. 38:34 itself: Solomon's mastery over the wind and the jinn (cf. Q. 21:82; Q. 34:12, Q. 38:36-8), and the gender and religious interaction within the Bilqis pericope (cf. Q. 27:15-44), both inform the interpretations that are given to the verse. Furthermore, the three explanations each provide us with an imprint of the Solomon character that is consistent with, and informed by, other aspects of his personality within the historiographical narratives.

To give an example, at the beginning of Tha ${ }^{c}$ labī and Ibn 'Asākir's Solomon narratives, one of the riddles Solomon must solve before he is named David's successor at the age of thirteen is: what is the most intimate thing (anas), and what the loneliest (awhash). The prophet answers that the most intimate thing is 'a body with a soul in it' (jasad fihi $r u \bar{h}$ ) and the loneliest 'a body without a soul in it' (jasad lā rūh fihi). ${ }^{98}$ All of the explanations provided in historiography for the Q. 38:34 passage are coherent with this ethos: the sense of solitary powerlessness that pervades the accounts of Solomon's attempts to save his child, the ultimate loneliness implicit in Solomon's various inappropriate passions, and the loneliness of his forty days of isolation awaiting God's forgiveness and the return of his sovereignty. In Kisā ${ }^{\overline{1}} \overline{\mathbf{1}}$, although the question is the same, the connotation is subtly different: there the opposition is between the best (ahsan) and, presumably, the worst (awhash) thing. ${ }^{99}$ Again, all the explanations for this passage show on one level or another that the body without the soul is the most dreadful of things - the body of Solomon's baby cast down from the clouds, the body that unbalances Solomon to such an extent that he has to forfeit his sovereignty and go into isolation, the body that is the demon Șakhr when he impersonates the king; they also however show how important the body is.

The symbolism in the Qur'anic verse Certainly We tried Solomon and We cast upon his throne a mere body also becomes clear through these passages, and with it the relevance and function of the stories themselves. Far from being dismissed, and dismissable, as khurāfät (fables), such tales are a powerful expression of the elucidation and rationalisation of Qur' anic material on the Solomonic figure by medieval historiographers and storytellers. As such, they deserve our consideration and attention. A reading of Q. 38:34, therefore, as informed by medieval Islamic historiographical narrative, suggests to us that the various Q. 38:34 episodes can be seen, as indeed can the other suggestions for the verse supplied by Fakhr al-Dīn al-Rāzī, as manifestations or physical embodiments of internal conflict. The death of Solomon's infant son 
expresses the prophet's difficulty in accepting his son's death, with the two 'deaths' of the child - when first his body is removed by the clouds and then it is cast down onto the throne - representing various stages in this process of acceptance; hence the phrase a mere body. In the case of the replacement of Solomon by his wazir , it seems more appropriate to see the mere body being referred to as Solomon's, prior to his seeking a period of isolation: the loosening of the ring of sovereignty on the prophet's finger represents the suggestion that the soul which made Solomon deserving of kingship is somehow perceived to be compromised or absent. The conflict therefore is between Solomon's sense of his own infatuation and his capacity for self-censure; the episode also however adds a nuance of dismissiveness towards the body described in the verse.

By far the richest allegory, and this perhaps is reflected in the fact that this is the most pervasive of the Q. 38:34 narratives, resides in the Șakhr pericopes. There the conflict between Solomon and his unconscious is embodied in a power struggle between the prophet and a demonic other. Yet despite a blurring of boundaries between the pair, the sense of two different personalities remains intact: the body referred to is clearly that of the demon. That this is also the explanatory narrative considered most problematic by commentators, both medieval and modern, is testament to the power of the narrative to discomfort and disturb; it goes without saying that, within a framework of psychoanalytic thought, any attempt to silence these concerns will be less effective a response than an exploration of the issues through dialogue. The psychological lessons exposed by the tale are multifaceted and defy easy epitomisation, but, as was made clear above, the answers to the questions the narrative raises are expertly resolved within the historiographical texts themselves.

\section{NOTES}

1 Commentators are divided on the issue of whether Solomon stroked his horses or slaughtered them. For a discussion of the arguments pertaining to this issue see Anthony H. Johns, 'Solomon and the Horses: The Theology and Exegesis of a Koranic Story, Sura $38(S \bar{a} d)$ : 30-33', MIDEO 23 (1997), pp. 259-82.

2 Translation taken from A.J. Arberry, The Koran Interpreted (Oxford University Press, 1983).

3 See Fakhr al-Dīn al-Rāzī, al-Tafsīr al-Kabīr (33 vols in 17. Beirut: Dār al-Kutub al-' Ilmiyya, 2000), vol. 26, pp. 181-2.

4 Historiography is treated on an equal footing with qișas for the purposes of this paper. The fifteenth century historian Sakhāwī classifies works of qișaș together with historiography in his text (see Sakhāwī, I'lān bi'l-tawbïkh (Beirut: Där al-Kutub al-' Ilmiyya, n.d.), pp. 171-2. Sakhāwī claims to be following Dhahabi in this regard) and, as will become clear, much of the material we find in qișas works is replicated in the world histories; moreover there is certainly evidence of movement between the two genres, with the historian Ibn Kathir for instance often citing the storyteller Tha ${ }^{c}$ labī (see e.g. in the Solomon story, Ibn Kathìr, Qisas al-anbiya $\bar{a}^{\supset}$, ed. Muhammad Ahmad ${ }^{c} A b d$ al- ${ }^{c} A z \bar{z}$ (Amman: Maktabat Dār al-Thaqāfa, 1989), p. 436, p. 440), 
who in turn adduces the earlier historian Tabarī (see e.g. in Cain and Abel, Tha ${ }^{\mathrm{c}} \mathrm{labī},{ }^{c} A r \bar{a}{ }^{\mathrm{a}} i s$

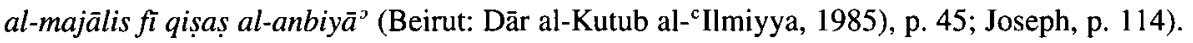
For a detailed list of material in Ibn al-Athīr derived from Tha'labī's Qișas and Ṭabarīs Tärīkh see M. Lidzbarski, De Prophetis, quae dicuntur legendis Arabicis, Friedrich Wilhelm, Berlin Univ. Diss. (Leipzig: Drugulin Printers, 1893), pp. 15-20.

5 'Umāra b. Wathīma b. Mūsā b. al-Furāt al-Fārisī al-Fasawī, Abū Rifāca, historian, d. 289/902. Some attribute this work not to ${ }^{c}$ Umāra but to his father Wathīma. For an Arabic edition of the text and detailed introduction see R.G. Khoury, Les légendes prophétiques dans l'Islam: Depuis le Ir jusqu'au III siècle de l'Hégire. Kitäb Bad' al-khalq wa-qișas al-anbiya ${ }^{\supset}$ : d'après le manuscript d'Abū Rifā́a 'Umāra b. Wathìma $b$. Mūsā $b$. al-Furāt al-Fārisĩ alFasawi: avec édition critique du text (Wiesbaden: Otto Harrassowitz, 1978), henceforward 'Umāra b. Wathīma, Kitāb Bad' al-khalq. See also R.G. Khoury, art. " Umāra b. Wathīma' in Encyclopaedia of Islam, $2^{\text {nd }}$ edn, vol. 10, pp. 835-6; H. Schwarzbaum, Biblical and Extra-biblical Legends in Islamic Folk-literature (Walldorf-Hessen: Verlag für Orientkunde Dr H. Vorndran, 1982), pp. 61-5 and the bibliography therein; R. Tottoli, Biblical Prophets in the Qur ān and Muslim Literature (Curzon, 2002), pp. 144-6.

6 Muhammad b. Jarī al-Ṭabarī, $\mathrm{Abū} \mathrm{Ja}^{\mathrm{c}}$ far, historian and mufassir, d. 923. There are countless Arabic editions of this work, and an English translation in several volumes published by State University of New York Press. The Solomon material is dealt with in vol. 3: W.M. Brinner, The History of al-Tabari, Volume Three: The Children of Israel (New York: State University of New York Press, 1991), pp. 152-74. For general information on Tabari and his history see e.g. W.M. Brinner (trans. \& annot.), 'Arä ${ }^{3}$ is al-Majāilis fi Qișaș al-Anbiy $\bar{a}^{3}$ or 'Lives of the Prophets': As Recounted by Abü Ishāq Ahmad b. Muhammad b. Ibrāhīm al-Tha' labī alNìsābūrī (Brill, 2002), pp. xix-xx; T. Nagel, Die Qișaș al-anbiya $\overline{ }^{2}$ : Ein Beitrag zur arabischen Literaturgeschichte (Bonn, 1967), pp. 16-28; C. Robinson, Islamic Historiography, esp. pp. 35-6, p. 79, pp. 137-8; F. Rosenthal, The History of al-Tabari. Vol. 1: General Introduction and From the Creation to the Flood (State University of New York Press, 1989), pp. 3-147; Tottoli, Biblical Prophets, esp. pp. 132-4.

7 Aḥmad b. Muhammad b. Ibrāhīm al-Tha ${ }^{c}$ labī al-Nīsābūrī, Abū Isḥāq, mufassir and traditionist, d. 427/1035. There are numerous Arabic editions of this text (Schwarzbaum states indeed that it is perhaps the most widely published book in the Middle East; see Schwarzbaum, Biblical and Extra-Biblical Legends, p. 65). An English translation has recently been published: Brinner, 'Arāais al-Majālis fi Qisas al-anbiy $\bar{a}^{3}$. For information on Tha'labi see the introduction to this work, also idem, 'Prophets and Prophecy in the Islamic and Judaic Traditions' in W.M. Brinner \& S.D. Ricks (eds), Studies in Islamic and Judaic Traditions II (Atlanta: Scholars Press, 1989), pp. 63-82, esp. p. 68; T. Nagel, Die Qisas al-Anbiyä (Bonn, 1967), pp. 80-103; Walid Saleh, The Formation of the Classical Tafsìr Tradition: The Qur ān Commentary of al-Tha labi (d. 427/1035) (Leiden: E.J. Brill, 2004); the introduction to W.M. Thackston Jnr (trans.), The Tales of the Prophets of al-Kisa' $i$ (Boston: Twayne Publishers, 1978); Tottoli, Biblical Prophets, esp. pp. 146-51.

8 We have no reliable biographical information for the putative author of this volume, leading some to suggest that it is a true work of folklore, ambiguous in authorship and date. For the Arabic edition see I. Eisenberg, Prophetarum auctore Muhammad ben Abdallah al-Kisa'i e codicibus, qui in Monaco, Bonna, Lugd. Batav., Lipsia et Gothana asservantur (2 vols. Leyden, 1922), hereafter Kisā̄î, Qișas al-anbiya $\bar{a}^{\jmath}$; for the English translation see Thackston, The Tales of the Prophets. For a discussion of the work see the introduction to this work and also e.g. Brinner, 'Prophets and Prophecy', p. 68; T. Nagel, art. 'Al-Kisā̄i ì' in Encyclopaedia of Islam, $2^{\text {nd }}$ edn, vol. 5, p. 176; idem, Die Qișaș al-anbiyā’ , pp. 122-49; J. Pauliny, 'Kisā’ī's Werk Kitāa Qișaș al-anbiya $\bar{a}^{\jmath}$, Graecolatina et Orientalia II (1970), pp. 191-282 and idem, 'Literarischer 
Charakter des Werkes Kisā̄̄̄'s Kitāb Qișaș al-anbiya $\bar{a}^{\jmath ’}$, Graecolatina et Orientalia III (1971), pp. 107-25; Tottoli, Biblical Prophets, esp. pp. 151-5.

9 Thiqat al-Dīn ${ }^{~} A$ Aī b. Abī Muhammad al-Hasan b. Hibat Allāh b. ${ }^{c}$ Abd Allāh b. al-Husayn b.

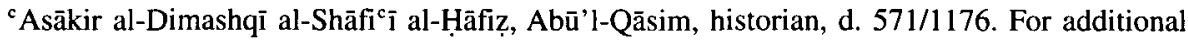
information on Ibn 'Asākir see N. Elisséeff, art. 'Ibn 'Asākir' in Encyclopaedia of Islam, $2^{\text {nd }}$ edn, vol. 3, pp. 713-15; J.E. Lindsay, " Alī b. ' Asākir as a preserver of Qisas al-Anbiyā': The Case of David b. Jesse', Studia Islamica 82 (1995), pp. 45-82; C. Robinson, Islamic Historiography, esp. p. 109.

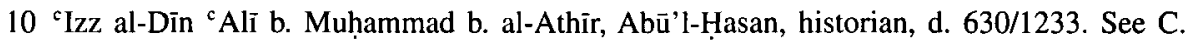
Cahen, 'The Historiography of the Seljuqid Period' in B. Lewis \& P.M. Holt, Historians of the Middle East (London: Oxford University Press, 1962), pp. 59-78 for some interesting references to Ibn al-Athir; Mona Joma Hammad, 'Latin and Muslim Historiography of the Crusades: A Comparative Study of William of Tyre and 'Izz al-Dīn Ibn al-Athīr' (UMI Dissertation Information Service, 1990), pp. 122-3 for a discussion of Ibn al-Athīr's historical methodology; Robinson, Islamic Historiography, esp. p. 98, p. 116; F. Rosenthal, art. 'Ibn alAthī' in Encyclopaedia of Islam, $2^{\text {nd }}$ edn, vol. 3, pp. 723-5.

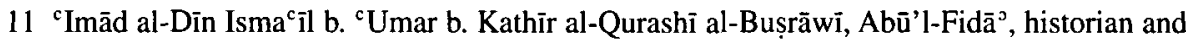
traditionist, d. 774/1373. The first volume of Ibn Kathir's world history is published as a separate volume under the title Qișaṣ al-anbiy $\bar{a}^{3}$. For additional information on Ibn Kathïr see e.g. Brinner, 'Arā ${ }^{\supset}$ is al-Majālis, pp. xxii-xxiii; N. Calder, 'Tafsīr from Ṭabarī to Ibn Kathīr: Problems in the Description of a Genre, Illustrated with Reference to the Story of Abraham' in G.R. Hawting \& A.K.A. Shareef (eds), Approaches to the Qur'an (London \& New York: Routledge, 1993), pp. 101-39, esp. pp. 120ff; H. Laoust, art. 'Ibn Kathïr' in Encyclopaedia of Islam, $2^{\text {nd }}$ edn, vol. 3, pp. 817-18; Robinson, Islamic Historiography, esp. pp. 134, 139, 144.

12 Muhammad ${ }^{\mathrm{c}}$ Abduh, al- $A^{\mathrm{c}}$ māl al-kāmila, ed. Muhammad ${ }^{\mathrm{c}}$ Imāra (Beirut: al-Mu'assasa al'Arabiyya li'l-Dirāsāt wa'l-Nashr, 1972-4), vol. 5, pp. 30ff. See also Khalafallah, al-Fann alqașași fi'l-Qur'ān al-karim (Cairo: Anglo-Egyptian Press, 1972), esp. p. 56, pp. 60-3, and Amīn al-Khūlī's introduction to the second edition of this work (Cairo, 1957), pp. dāl and $h \bar{a}^{j}$. 'Abduh's thought on this matter is widely adduced by subsequent writers. See for instance Aziz al-Azmeh, 'The Muslim Canon from Late Antiquity to the Era of Modernism' in A. Van der Kooij \& K. Van der Toorn (eds), Canonization and Decanonization: Papers Presented to the International Conference of the Leiden Institute for the Study of Religions (LISOR), Held at Leiden 9-10 January 1997 (Brill, 1998), pp. 191-228, esp. pp. 215-8; Nasr Abu Zayd, 'The Dilemma of the Literary Approach to the Qur'an', Alif 23 (2003), pp. 8-47, esp. pp. 25-6 where Abu Zayd describes how Khalafallah implemented 'Abduh's thesis in his own thought; Roberto Tottoli, Biblical Prophets in the Qur'an and Muslim Literature (Curzon, 2002) meanwhile focuses his analysis of ${ }^{\mathrm{c}}$ Abduh's thesis on the rejection of so-called isrä $\bar{a}^{\circ}$ iliyyāt and subsequent changes to the qișas genre, see pp. 176-7. See also below endnote 44. It is interesting in this context to consider Julie Scott Meisami's comment regarding Persian historiography, 'the medieval historian's primary interest lay less in recording the 'facts' of history than in the construction of a meaningful narrative'. See J.S. Meisami, Persian Historiography to the End of the Twelfth Century (Edinburgh University Press, 1999), p. 3.

13 See ${ }^{\mathrm{c}}$ Umāra b. Wathīma, Kitāb Bad ${ }^{3}$ al-khalq, p. 154, citing Abū Hurayra; Tha' labī, ${ }^{c}$ Arã ${ }^{\circ}$ is al-majālis, p. 326, citing Sha ${ }^{c}$ bì. See also Fakhr al-Dīn al-Rāzī, al-Tafsìr al-kabìr, vol. 26, p. 183 for a version of this story.

14 See Tha' ${ }^{\mathrm{c}} \mathrm{labī},{ }^{\mathrm{c}}$ Arä ${ }^{\mathrm{j}}$ is al-majälis, p. 325.

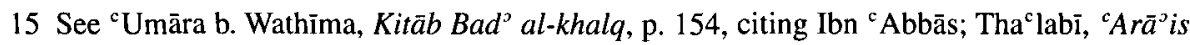
al-majālis, p. 322, citing Ibn Isḥāq. 


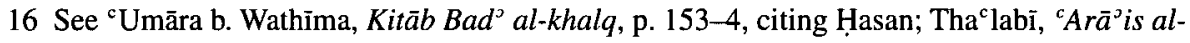

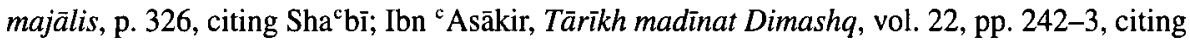
Hasan. It is worthy of note that both ${ }^{\mathrm{c}}$ Umāra b. Wathima and Ibn ${ }^{\mathrm{c}}$ Asākir add the explanation that Solomon did all this out of solicitude for the child (shafaqatan 'alayhi). Ibn 'Asākir also gives another, sparser, variant of the tale. See Ibn ' ${ }^{\mathrm{C}}$ Asākir, Tārikh madīnat Dimashq, vol. 22, p. 243, citing Sha ${ }^{c}$ bì.

17 'Umāra b. Wathīma, Kitāb Bad' al-khalq, pp. 153-4, attributed to Abu Hurayra; Ibn 'Asākir, Tārīkh madīnat Dimashq, vol. 22, pp. 257-9; Ibn Kathīr, Qișaṣ al-anbiyä’, pp. 446-8, citing hadīth from Bukhārī, Abū Ya ${ }^{c}$ lā and Aḥmad, also Abū Hurayra. Cf. Fakhr al-Dīn al-Rāzī, al-Tafsir al-kabir, vol. 26, p. 182.

18 The presence of God's controlling hand over the powers He grants Solomon is moreover implicit in Q.21:82, And to Solomon the wind, strongly blowing, that ran at his command unto the land that We had blessed; and We had knowledge of everything; and of the Satans some dived for him and did other work besides; and We were watching over them (Arberry, emphasis mine).

19 P.J. Awn, Satan's Tragedy and Redemption: Iblis in Sufi psychology (Leiden: E.J. Brill, 1983), p. 19. Although the Qur'anic verses he adduces in support of this aspect of Iblis' personality seem rather to be references to the devil's power to entice and convince, his statement nonetheless rings true. It is interesting to see quite a different manifestation of this story appearing in Bruno Bettelheim's study of the purposes of fairy tales in the psychology of children. Bettelheim writes that (B. Bettelheim, The Uses of Enchantment: The Meaning and Importance of Fairy Tales (London: Penguin, 1991), p. 70) 'The motif that parents who too impatiently desire to have children are punished by giving birth to strange mixtures of human and animal beings is an ancient one, and widely distributed. For example, it is the topic of a Turkish tale in which King Solomon effects the restitution of a child to full humanity. In these stories, if the parents treat the misdeveloped child well and with great patience, he is eventually restored as an attractive human being.' The three versions of the episode we are dealing with here, however, do not fit into the Turkish mould. In historiography the lesson would seem not to be that affectionate parenting yields great rewards, but that parents should not arrogantly claim sole responsibility in their children's welfare. Thus neither 'Umāra b. Wathīma, Ibn 'Asākir or Ibn Kathir bother to include any ending to the tale: by citing the beginning of this story they have achieved their purpose. It is possible that the story ends as Bettelheim points out; it is also however possible that the two versions of the malformed child story are in fact just one: that the half-child born in the second anecdote is the selfsame child Solomon gives to the clouds to protect.

20 See Tha ${ }^{c}$ labī, ${ }^{c} A r \bar{a}^{\circ}$ is al-majālis, p. 326.

21 See Tha' ${ }^{c}$ labī, ${ }^{c} A r \bar{a}^{2}$ is al-majālis, pp. 304-5, citing Wahb b. Munabbih.

22 Cf. Fakhr al-Dīn al-Rāzī, al-Tafsìr al-kabìr, vol. 26, p. 182, who tells us that Solomon's sin was in not putting his trust in God, 'lam yatawakkal fihi 'alä'lläh'.

23 Cf. 'Umāra b. Wathīma, Kitāb Bad' al-khalq, p. 165; Ṭabarī, Tārīkh al-umam wa'l-mulūk (5 vols. Beirut: Dār al-Kutub al-' Ilmiyya, 1987), vol. 1, p. 295, citing Suddī; Ibn al-Athīr, alKāmil fi'l-tārīkh, ed. Abū'l-Fidā’ 'Abd Allāh al-Qāḍī (10 vols. Beirut: Dār al-Kutub al'Ilmiyya, 1987), vol. 1, p. 185.

24 Āṣaf b. Barkhiyâa $\bar{a}^{\supset}$ is alternately often described as Solomon's scribe (kātib), also sometimes as his cousin. Cf. for example 'Umāra b. Wathīma, Kitäb Bad' al-khalq, p. 144, citing Ibn ${ }^{\mathrm{c}}$ Abbās.

25 See Tha ${ }^{c}$ labi, ${ }^{c}$ Ară ${ }^{\circ}$ is al-majālis, p. 325.

26 I rely for this account of Tha 'labī's text on Nizāàm al-Dīn al-Nīsābūrī (d. 728/1328), Tafsīr 
Gharā̄ib al-Qur ān wa-raghā̄ib al-furqān (5 vols. Beirut: Dār al-Kutub al-``Ilmiyya, 1996), vol. 5, p. 596. Although Tha' labī's tafsir has recently been published, it is not widely available. See Tha ${ }^{c}$ labī, al-Kashf wa'l-bayān ' an Tafsìr al-Qur'ān, ed. Imām Abū Muhammad b. 'Ashūr (10 vols. Beirut: Dār Ihyā $\overline{ }^{\mathfrak{j}}$ al-Turāth al- ${ }^{\mathrm{c}}$ Arabī, 2002). For a detailed critique of the edition, see Saleh, The Formation of the Classical Tafsir Tradition, pp. 229-30.

27 Fakhr al-Dīn al-Rāzī, al-Tafsīr al-kabìr, vol. 26, p. 181.

28 See Țabarī, Tārïkh al-umam wa'l-mulük, vol. 1, p. 293, citing Wahb b. Munabbih; Tha' labī, ${ }^{c}$ Arä’is al-majālis, p. 322; 'Umāra b. Wathìma, Kitāb Bad' al-khalq, p. 155 where Iblīs sees this as his opening; and Ibn 'Asākir, Tārikh madinat Dimashq, vol. 22, p. 243. Cf. also Ibn alAthīr, al-Kāmil fíl-tārīkh, p. 183, 'wa-ahabbahā hubban shadīdan'.

29 In Tha clabi we are told she only pretends to convert (aslamat ... fi'l-zähir), through fear of Solomon ( ${ }^{c}$ alä khïfatin minhu). See Tha ${ }^{c}$ labī, ${ }^{c}$ Arā ${ }^{\top}$ is al-majālis, p. 322. That her conversion was not wholehearted is also suggested in Tabari, aslamat ${ }^{c}$ ala jafa ${ }^{3}$ in minha wa-qillat thiqqa. See Țabarī, Tärīkh al-umam wa'l-mulük, vol. 1, p. 293, citing Wahb b. Munabbih. Cf. also Ibn al-Athīr, al-Kämil fì'l-tärïkh, vol. 1, p. 183.

30 See Tabarī, Tärīkh al-umam wa'l-mulūk, vol. 1, p. 293, citing Wahb b. Munabbih.

31 See endnote 41 below.

32 It is moreover made evident that the prophet feels himself to have been compromised by the worshipping of other gods within his family. Thus Tabarī, during Solomon's repentance to

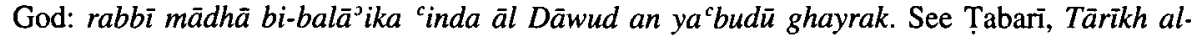
umam wa'l-mulük, vol. 1, p. 294, citing Wahb b. Munabbih.

33 Nīsābūrī comments that such practices may well have been permitted according to what was then contemporary law. See Nīsābūrī, Tafsīr Gharāaib al-Qur ān, vol. 5, p. 596. This is a familiar argument. Cf. Ibn Kathir who takes a similar stand when discussing aspects of the horses episode, Qișas al-anbiya $\vec{a}^{3}$, p. 441.

34 'Umāra b. Wathīma, Kitāb Bad' al-khalq, p. 157; Țabarī, Tārīkh al-umam wa'l-mulūk, vol. 1, p. 294, citing Wahb b. Munabbih; Ibn al-Athīr, al-Kämil fi'l-tārïkh, vol. 1, p. 184.

35 Ibn 'Asākir, Tārīkh madinat Dimashq, vol. 22, pp. 246-7, citing Wahb b. Munabbih. It seems worthy of note that, when the wife hears about her husband's period of exile, her sadness at his plight causes her to convert to Islam. Ibn ' Asākir also gives another anecdote in which Solomon's Magian wife presses him to sacrifice something to her god until he concedes to a locust. After killing it, God causes him to forget about his actions until later, when he loses his throne. See Ibn 'Asākir, Tārīkh madīnat Dimashq, vol. 22, pp. 247-8, citing Duwayd b. Nāfic .

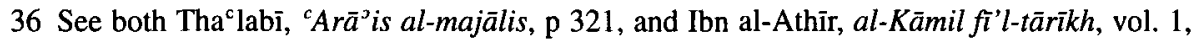
p. 181.

37 Q. 12:23-6. For this story in historiography see Tabarī, Tārīkh al-umam wa'l-mulūk, vol.

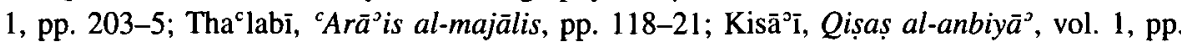

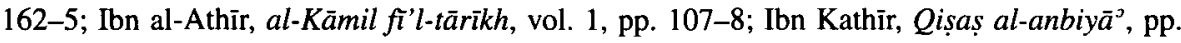
208-9. For a commentary on Joseph and Zulaikha see e.g. J.W. Clinton, 'Joseph, Yusuf, Siyavosh: Reflections on the Chaste Youth as Culture Hero', Edebiyat (New Series) 1:1 (1987), pp. 90-102. See also J. Scott Meisami (trans.), The Sea of Precious Virtues - Bahr al-Favā ${ }^{\supset}$ id: A Medieval Islamic Mirror for Princes (University of Utah Press, 1991), p. 18; T.J. Winter (trans.), Al-Ghazāli on Disciplining the Soul (Kitāb Riyādat al-nafs) and on Breaking the Two Desires (Kitäb Kasr al-shahwatayn): Books XXII and XXIII of the Revival of the Religious Sciences (Ihyāj 'ulüm al-dīn) (Cambridge: Islamic Texts Society, 1995), esp. pp. 184-6. In both of these sources Joseph's humility at having found the strength to resist Zulaykha's advances is made clear. 
38 Cf. Q. 38:21-5, and note the similarity in wording across the two episodes: of David we are told fatannāhu ... wa-anāba; of Solomon wa-la-qad fatannā Sulaymān ... thumma anāba. For this story in historiography see 'Umāra b. Wathìma, Kitāb Bad' al-khalq, pp. 103-21; Tabarī, Tārīkh al-umam wa'l-mulūk, vol. 1, pp. 282-5; Tha ${ }^{c} l a b \overline{1},{ }^{c}$ Arä ${ }^{\top}$ is al-majālis, pp. 279-86; Kisā̄ī, Qisas al-anbiyă ${ }^{2}$, vol. 2, pp. 262-3; Ibn al-Athīr, al-Kāmil fíl-tārīkh, vol. 1, pp. 170-2. Ibn Kathir refers to the Qur' anic verse but does not provide any explanation, stating that most of the anecdotes supplied are isra $\bar{a}^{\supset} \bar{l}$ liyyāt. See Ibn Kathīr, Qișas al-anbiy $\bar{a}^{\supset}$, p. 424. For a commentary on David's situation see e.g. A.H. Johns, 'David and Bathsheba: A Case Study in the Exegesis of Qur' anic Story-telling', MIDEO 19 (1989), pp. 225-66; Lindsay, Studia Islamica 82 , pp. $78-80$.

39 The name supplied by Suddī for the ring-bearer is Jarāda. See Tabarī, Târīkh al-umam wa'l-mulük, vol. 1, p. 295.

40 See 'Umāra b. Wathīma, Kitāb Bad ${ }^{\supset}$ al-khalq, p. 159, citing Wahb b. Munabbih; Țabarī, Tārīkh al-umam wa'l-mulük, vol. 1, p. 294, citing Wahb b. Munabbih; Ibn 'Asākir, Tārīkh madinat Dimashq, vol. 22, p. 246. Cf. Tha ${ }^{\mathrm{c}} \mathrm{labi},{ }^{\circ}$ Arā'is al-majālis, p. 323, 'fa- ${ }^{c}$ arafa Sulaymān anna'l-khatī'a qad adrakathu', and, p. 324, 'wa- 'alima anna'lladhi dakhala 'alayhi limā ahdatha fì dārihi min 'ibādat al-wathan'; Kisā'̄ī, vol. 2, p. 294, 'fa- 'alima Sulaymān annahu qad uftutina wa-umtuhina fa-kharaja hāriban' and 'qad nuzi 'a mulkī minnī li-khațī' $a$ '; Ibn alAthīr, al-Kämil fì'l-tärīkh, vol. 1, p. 184 'fa- 'arafa Sulaymān khați ${ }^{\top} a t a h u$ ' and, p. 185, where he also states that Șakhr occupies the throne for the same length of time as the idol was worshipped in Solomon's house, making a direct link between the two events. Tabarī also makes this link, see Tabarī, Tārīkh al-umam wa'l-mulūk, vol. 1, p. 294, citing Wahb b. Munabbih. Cf. also Fakhr al-Dīn al-Rāzī, al-Tafsīr al-kabìr, vol. 26, p. 181, 'fa- 'arafa anna'l-khațī’a qad adrakathu'.

41 For this narrative see ' Umāra b. Wathīma, Kitāb Bad al-khalq, pp. 154-64; Tabarī, Tārīkh

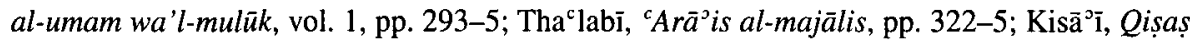
al-anbiy $\bar{a}^{\supset}$, vol. 2, pp. 293-5; Ibn ${ }^{\circ}$ Asākir, Tärīkh madīnat Dimashq, vol. 22, pp. 243-6; Ibn al-Athīr, al-Kämil fíl'-tārïkh, vol. 1, pp. 182-5. See also Fakhr al-Dīn al-Rāzī, al-Tafsìr al$k a b i r$, vol. 26, p. 181 where this anecdote is given in all its salient details, Ibn Kathir, Tafsìr alQur ān al- ${ }^{c} a z \bar{i} m$, ed. Yūsuf ${ }^{\mathrm{c}} \mathrm{Abd}$ al-Raḥmān al-Mar'ashalī (4 vols. Beirut: Dār al-Ma ${ }^{\mathrm{c}}$ rifa, 1987), vol. 4, pp. 38-40, and a plethora of other sources, e.g. Ibn al-Jawzì, al-Tabșira (Beirut: Dār al-Kutub al-'`lmiyya, 1986), vol. 1, pp. 295-300.

42 See Ṭabarī, Tārīkh al-umam wa'l-mulūk, vol. 1, p. 285; Tha' labī, 'Arǟis al-majālis, p. 287; Kisā̄ī, Qișas al-anbiyā̄, vol. 2, p. 264; Ibn al-Athīr, al-Kāmil fí'l-tārīkh, p. 183.

43 R. Girard, Violence and the Sacred (London: John Hopkins, 1977), p. 150.

44 Ibn Kathir refers his readers to his Tafsì where several versions of this story are given (see Ibn Kathìr, Tafsīr al-Qur ān al- ${ }^{c} a z \bar{z} m$, vol. 4, pp. 38-40). In the History he comments that most of the 'body on the throne' story consists of isra $\bar{a}^{\supset} \bar{l}$ liyyāt (Ibn Kathìr, Qisas al-anbiy $\bar{a}^{\jmath}$, p. 422); in this context, it is interesting to compare the Midrashic tales as expressed in L. Ginzberg, The Legends of the Jews (Philadelphia: The Jewish Publication Society, 1947), vol. 4, pp. 125-76. Although there are some parallels between these and certain of the historiographical episodes, it is in fact noteworthy how little overlap there is between the two traditions.

45 See Ibn al-Athīr, al-Kāmil fì'l-tārīkh, vol. 1, pp. 182-3, citing the opinions of Abū Shuhba.

46 The signet ring can be read as the embodiment of the substantive kudos. Girard writes that 'those who possess kudos see their strength multiplied a hundredfold; those deprived of it discover that they are hopelessly handicapped' (Girard, Violence and the Sacred, p. 152); he also states that it is a prize both conferred and removed by the gods, at their discretion. The sources accordingly give various descriptions of the ring's powers, among them that it causes men and 
jinn to submit to Solomon's command (cf. 'Umāra b. Wathīma, Kitāb Bad al-khalq, p. 158; Tha ${ }^{c}$ labì, ${ }^{c} A r \bar{a}^{\top}$ is al-majālis, p. 291, p. 309; Ibn 'Asäkir, Tärïkh madīnat Dimashq, vol. 22, p. 245, citing Wahb b. Munabbih; Ibn al-Athīr, al-Kāmil fíl l-târīkh, vol. 1, p. 185). Kisāāi adds the intriguing details that the ring formerly belonged to Adam, but was taken from him when he was expelled from Paradise (see Kisā ${ }^{3} \overline{1}$, Qișas al-anbiy $\vec{a}^{3}$, vol. 2, pp. 278-9), and that the rebellious Șakhr, who refused to be subjugated to the ring before Solomon's loss of power, bowed down to it after power is restored to the king (p. 319), adding to our impression that the sovereignty that resides in the ring is a variable bestowed by God.

47 See Fakhr al-Dīn al-Rāzī, al-Tafsìr al-kabir, vol. 26, p. 182.

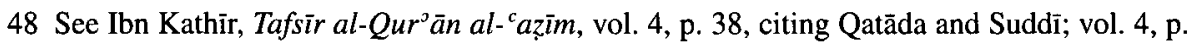
39, citing Ibn 'Abbās, where denial of the demon is placed in the Israelites' hearts by God.

$49 \mathrm{See}^{\mathrm{C} U m a ̄ r a ~ b . ~ W a t h i ̄ m a, ~ K i t a ̄ a ~ B a d ~}{ }^{’}$ al-khalq, p. 164, Tabarī, Tārīkh al-umam wa'l-mulük, vol. 1, p. 294, citing Wahb b. Munabbih; Tha ${ }^{c}$ labī, ${ }^{c}$ Ară ${ }^{\circ}$ is al-majālis, p. 324, citing Ibn Ishāq; Ibn 'A Asākir, Tārikh madinat Dimashq, vol. 22, p. 251, citing Ḥasan; Ibn al-Athīr, al-Kāmil fì'ltārīkh, p. 184. Cf. Kisā̄̄ī, Qișas al-anbiyā', p. 318, citing Ibn 'Abbās, 'The people also began to hear things they had never before heard about Solomon.'

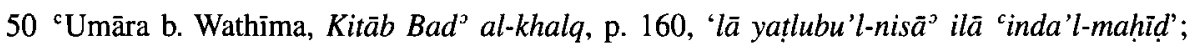
also Ibn 'Asākir, Tārīkh madīnat Dimashq, vol. 22, p. 253, citing Hasan, 'lā yatlubu'l-nisā' ilā 'inda'l-hayd'.

51 Ibn 'Asākir, Tārīkh madīnat Dimashq, vol. 22, p. 252, 'kāna ya ${ }^{\top} t \bar{t}$ nisā’ahu fa-innamā ankarnāhu li-annahu kāna ya tĩ nisă $\bar{J}^{3}$ ahu wa-hunna huyyid' and p. 253 where the answer to Āsaf's inquiry as to whether the wives have allowed 'Solomon' access is a categorical 'No' (qāla: hal tu’tīnahu. qulna: lā); cf. 'Umāra b. Wathīma, Kitāb Bad' al-khalq, p. 160, citing Hasan.

52 For the importance of ritual cleansing in the workings of the devil see Awn, Satan's Tragedy and Redemption; Winter, al-Ghazäli on Disciplining the Soul. The Bahr al-Favā ${ }^{\supset} i d$ is an interesting source for allusions to how ritual purity was perceived. See Meisami, The Sea of Precious Virtues, esp. pp. 22, 65, 100, 103, 179.

53 Prayer is highly effective in protecting the believer against Iblīs, who flees, albeit temporarily, whenever he hears the call to prayer. See Awn, Satan's Tragedy and Redemption, p. 51, citing Muslim 2:5-6.

54 See the Bahr al-Favä id on intercourse during menstruation: 'If this is done and the doer considers this lawful, he is an unbeliever; and if he does not think it lawful he is a sinner.' Meisami, The Sea of Precious Virtues, p. 97.

55 See T.J. Winter, al-Ghazālī. The Remembrance of Death and the Afterlife. Kitāb Dhikr almawt wa-mā bacdahu. Book XL of the Revival of the Religious Sciences. Ihy $\bar{a}^{\supset}$ 'ulüm al-din (Cambridge: Islamic Texts Society, 1989), p. 156, who cites the following hadìth from Bukhārī (' $I l m$ ', 38) and Muslim ('Ru' ${ }^{\circ} \mathrm{ya}$ ', 10): 'Whoever sees me in his sleep has seen me truly, for the devil does not assume my form.'

56 It is also interesting for our purposes to consider the implication of the so-called Satanic Verses episode on this issue. The relevant part of Tabarī's account is as follows (see Tabari, Tärīkh al-umam wa'l-mulük, vol. 1, pp. 550-2, citing Muhammad b. $\mathrm{Ka}^{\mathrm{c}} \mathrm{b}$ al-Qurazī and Muhammmad b. Qays; this anecdote is widely refuted, cf. for instance Rāzì, al-Tafsìr al-kabìr, vol. 23, pp. 44-8, also modern scholars such as Tammām Hassān, al-Bayän fí rawä ${ }^{\jmath} i^{c}$ alQur ān (2 vols in 1. Cairo: ' ${ }^{\circ}$ Alam al-Kutub, 2000), vol. 2, pp. 326-30): the devil is reported to have cast words onto Muhammad's tongue while he was reciting the Qur'an (alqä'l-Shaytān 'alā lisānihi: note the use of the verb alqā as in Q. 38:34), causing him to say of the idols worshipped locally, 'These are the exalted Females, And verily their intercession is to be hoped 
for,' (for this translation see J. Burton, 'These are the High-flying Cranes' in A. Rippin (ed.), The Qur ān: Formative Interpretation (Ashgate: Variorum, 1999), pp. 347-66, here citing W. Muir, The Life of Mahomet (London, 1877), p. 86) much to the delight of his audience of Meccans. Gabriel however informs the Prophet of what he has done, and he is immediately repentant and fearful. God therefore sends a verse to remove these words, saying, We sent not ever any Messenger or Prophet before thee, but that Satan cast into his fancy, when he was fancying; but God annuls what Satan casts, then God confirms His signs ... (Q. 22:52; again note the use of the verb). The parallels with the Solomon situation are intriguing: demonic interpolation, prophetic repentance, and ultimate divine intervention to remedy the situation. We can also perceive in both the insidious presence of the devil, and evidence of God's watchful eye over His revelation and legislation.

57 'Umāra b. Wathīma, Kitäb Bad' al-khalq, p. 159, citing Hasan.

58 See Ṭabarī, Tärīkh al-umam wa'l-mulük, vol. 1, p. 295, citing Suddī, 'fa-qāma ilayhi baghduhum fa-ḍarabahu bi- 'așan fa-shajjahu'; Kisāāi, Qișaș al-anbiyā', vol. 2, p. 294, 'ḍarabahu bi- 'asāhu 'alā ra'sihi'; Ibn 'Asākir, Tārīkh madīnat Dimashq, vol. 22, p. 250, 'đạabahu bimurdiyy'; Ibn al-Athīr, al-Kāmil fì'l-tārīkh, vol. 1, p. 185, 'kadhdhabahu wa-darabahu wa-shajjahu'; cf. Ibn Kathīr, Tafsìr al-Qur ān al- ${ }^{c} a z \bar{i} m$, vol. 4, p. 39, citing Suddī. One is immediately struck by the parallels with Noah's situation as described in the historiographical narrative. Cf. Tha ${ }^{\mathrm{c}}$ labī, 'Arā'is al-majālis, p. 55, where we are similarly told that the prophet is attacked (inna Nühan kāna yudrabu) and also beaten with a stick (darabahu bi- ${ }^{c} a s ̧ a n$ ). The accusations of madness and lying also instantly recall Qur' anic passages which describe the treatment of prophets. The fact that here, in the Solomonic narrative, the prophet is vilified not because the people are disbelievers but because they do not recognise in him their beloved and familiar prophet adds an interesting twist to an archetypal situation.

59 Thus 'Umāra b. Wathīma, Kitāb Bad' al-khalq, pp. 159-60, and Ibn ' Asākir, Tārīkh madinat Dimashq, vol. 22, p. 254, both citing Hasan.

60 Awn, Satan's Tragedy and Redemption, p. 44. For an interesting example of Freud's attitude to the devil see S. Freud, A Seventeenth Century Demonological Neurosis (Vintage: The Standard Edition of the Complete Psychological Works of Sigmund Freud, vol. xix (1923-5), 2001), pp. 85-7.

61 See e.g. Tha ${ }^{c}$ labī, ${ }^{c}$ Arä ${ }^{j}$ is al-majālis, p. 34.

62 Kisā̄ ${ }^{\supset}$, Qișas al-anbiy $\bar{a}^{\supset}$, vol. 2, p. 279.

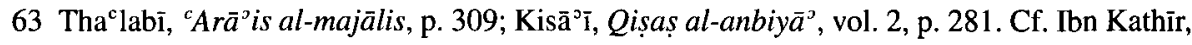
Tafsìr al-Qur'ān al- ${ }^{c} a z$ ìm, vol. 4, p. 38, citing Qatāda.

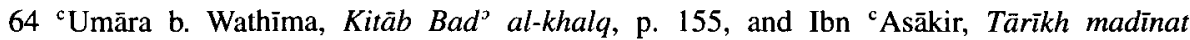
Dimashq, vol. 22, p. 244, citing Ibn ${ }^{\mathrm{c}}$ Abbās. In both accounts Iblīs sends Ṣakhr to complete this task.

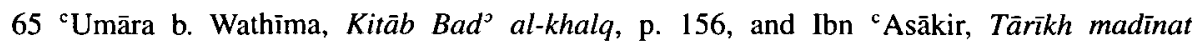
Dimashq, vol. 22, p. 244, citing Ibn ' Abbās.

66 'Umāra b. Wathīma, Kitāb Bad' al-khalq, pp. 161-2, and Ibn ' Asäkir, Tārīkh madinat Dimashq, vol. 22, pp. 249-50, citing Ibn Simª̄n, Ibn Isḥāq et al.

67 See 'Umāra b. Wathīma, Kitāb Bad' al-khalq, pp. 158-9; TTabarī, Tãrīkh al-umam wa'lmulük, vol. 1, p. 294; Tha' labī, 'Arä'is al-majālis, p. 323; Ibn 'Asākir, Tārīkh madinat Dimashq, vol. 22, pp. 245-6; Ibn al-Athīr, al-Kämil fìl-tārỉkh, vol. 1, p. 184. Cf. Ibn Kathīr, Tafsìr al-Qur'ān al- ${ }^{c} a z \bar{i} m$, vol. 4, pp. 38-40.

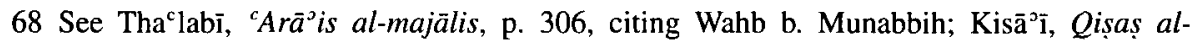
anbiy $\tilde{a}^{J}$, vol. 2, p. 283. Presumably it is because Șakhr built the throne that he is the only per- 
son other than Solomon capable of ascending it (Tha' labi, ' ${ }^{c}$ Arä ${ }^{3}$ is al-majālis, p. 306). Cf. Ibn Kathīr, Tafsīr al-Qur'ān al- ${ }^{c} a z i ̄ m$, vol. 4, p. 40, citing Ibn Isḥāq.

69 See Tha ${ }^{c}$ labī, ${ }^{c}$ Ară ${ }^{3}$ is al-majālis, p. 323.

70 See Ibn 'Asākir, Tārīkh madinat Dimashq, vol. 22, p. 249.

71 'Umāra b. Wathīma, Kitāb Bad' al-khalq, p. 162.

72 See Kisā̄ō, Qișaș al-anbiya $\tilde{a}^{\supset}$, vol. 2, p. 293, 'thumma banä lahu Șakhr al-Mārid qașran 'alā sāhil al-baḥr wa-nazala Șakhr mac ahu fi dhãlika'l-qaṣr'.

73 Awn, Satan's Tragedy and Redemption, p. 46, argues that this impression of Iblis is prevalent in hadīth.

74 This story exists in Ibn ${ }^{c}$ Asākir in all its salient details, but the demon there is named Zawba ${ }^{\mathrm{c}}$ a. See Ibn ${ }^{\mathrm{c}}$ Asākir, Tārīkh madīnat Dimashq, vol. 22, p. 291, citing Qurra b. ${ }^{\mathrm{c} A t ̣ i y y a . ~}$ Cf. Ibn 'Asākir, Tārīkh madïnat Dimashq, p. 292.

75 See Alf Layla for examples of demons formerly imprisoned by Solomon reappearing from the depths of the sea. In Kisā̄ī, Qișaș al-anbiyā’ vol. 2, p. 268, Iblīs sinks into the sea for seventy days when Solomon is born. Șakhr, however, is cast not into the sea but into a lake (Kisāāi, Qisas al-anbiy $\bar{a}^{\supset}$, vol. 2, p. 319). Water plays a further role: when Solomon eventually finds a piece of dry bread to eat, a wave snatches the bread from his hand (Kisā̄î, Qișas al-anbiy $\bar{a}^{2}$, vol. 2, p. 294; Ibn 'Asākir, Tārīkh madīnat Dimashq, vol. 22, p. 253).

$76 \mathrm{Tha}^{\mathrm{C}}$ labī, 'Arä ${ }^{\mathrm{D}}$ is al-majälis, p. 304, citing Wahb b. Munabbih. The bottom of the sea, we are told, is more than forty years journey away.

77 See Kisā ${ }^{\supset} \overline{\mathbf{1}}$, Qișas al-anbiy $\bar{a}^{\supset}$, vol. 2, pp. 280-1. This echoes David's request to be allowed

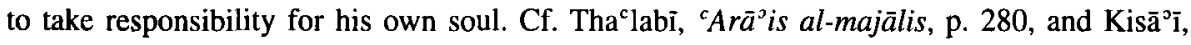
Qișas al-anbiya $\bar{a}^{2}$, vol. 2, pp. 260-1, where the echo is even more pronounced.

78 See e.g. C.G. Jung, The Archetypes and the Collective Unconscious, trans. R.F.C. Hull (London: Routledge \& Kegan Paul, 1968), pp. 177-8.

79 Wendy Doniger O'Flaherty, Other People's Myths: The Cave of Echoes (Chicago \& London: University of Chicago Press, 1995), p. 81.

80 Thus Țabarī, Tārīkh al-umam wa'l-mulūk, vol. 1, p. 295 and Tha ${ }^{c} l a b \overline{1},{ }^{c} A r a{ }^{\top}$ is al-majālis, p. 324, both citing Suddī, also Ibn al-Athīr, al-Kāmil fí'l-tārīkh, vol. 1, p. 185 (cf. Ibn Kathīr, Tafsir al-Qur ān al-'azim, vol. 4, p. 38, citing Suddī). The context for this detail is however that Solomon loses his throne to the demon on account of his failure to keep his word in resolving his wife's brother's dispute, not the worship of an idol in the prophet's household.

81 'Umāra b. Wathīma, Kitāb Bad' al-khalq, p. 163, tells us the people called Solomon a liar for claiming to be the king; Tabari, Tărīkh al-umam wa'l-mulūk, vol. 1, p. 294, tells us he was accused of madness; Tha ${ }^{c}$ labī, ${ }^{c} A r \bar{a}^{3}$ is al-majālis, p. 323, has Solomon unrecognisable to his people and slavegirls, but again does not specify the form the prophet takes; Ibn ${ }^{\mathrm{C}}$ Asākir, Tārīkh madinat Dimashq, vol. 22, p. 246, writes 'qad taghayyara 'an hălihi wa-dhahaba 'anhu bahä ${ }^{3} u h u^{\prime} ;$ Ibn al-Athìr, al-Kāmil fi'l-tārîkh, p. 184, tells us that Solomon's form and condition had changed, and he is called a liar for his claim to be Solomon. Cf. Ibn Kathïr, Tafsïr al-Qur ${ }^{2} \bar{a} n$ al- ${ }^{c} a$ żìm, vol. 4, p. 39, citing Ibn ' Abbās.

82 Kisā̄ì, Qisas al-anbiyā', vol. 2, p. 294, tells us 'wa-qad alqā'llāh 'alayhi shabah Șakhr wa-ghayyara șüratahu'.

83 'Umāra b. Wathīma, Kitāb Bad' al-khalq, p. 155, citing Ibn 'Abbās.

84 Girard, Violence and the Sacred, p. 159.

85 Bettelheim, The Uses of Enchantment, pp. 90-6.

86 Bettelheim, The Uses of Enchantment, p. 96. 
87 J. Knappert, 'The Qișașu'l-Anbiyā’i as Moralistic Stories', Proceedings of the Seminar for Arabian Studies Volume 6 (London Institute of Archaeology, 1976), pp. 103-16, p. 112.

$88 \mathrm{Tha}^{\mathrm{c}} \mathrm{labi},{ }^{\mathrm{C}}$ Arä $\bar{a}^{\top}$ is al-majālis, p. 293.

89 For this account see ${ }^{\mathrm{C}}$ Umāra b. Wathīma, Kitāb Bad ${ }^{\mathrm{D}}$ al-khalq, pp. 151-3; Tha ${ }^{\mathrm{c}} \mathrm{labī},{ }^{c} \mathrm{Ara} \bar{a}^{\mathrm{j}}$ is

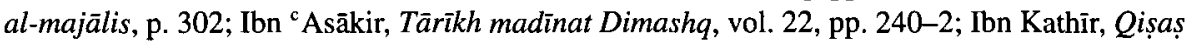
al-anbiy $\tilde{a}^{2}$, p. 441 . It should be stressed, however, that all of these sources also give alternative interpretations of this passage, among them that Solomon stroked the horses rather than slaughtering them.

$90 \mathrm{Ibn}$ Kathìr, Qișas al-anbiya $\bar{a}^{3}$,p. 434, citing a hadīth on the authority of Ibn Mājah; cf. Ibn 'Asākir, Tãrikh madinat Dimashq, vol. 22, p. 276.

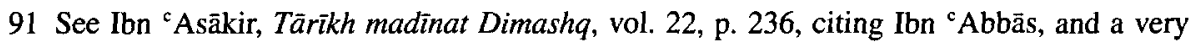

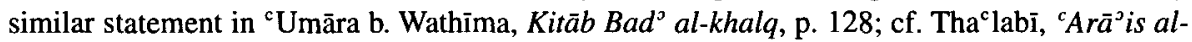
majālis, p. 296, where an ant warns Solomon 'lā tastaghiqu fi shahawātika wa-dahāakika'.

92 See Tabarī, Tärīkh al-umam wa'l-mulük, vol. 1, pp. 290-2; 'Umāra b. Wathīma, Kitäb Bad ${ }^{\text {' }}$

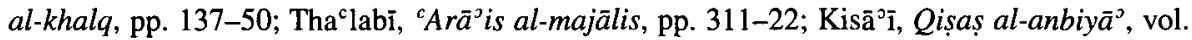
2, pp. 285-93; Ibn al-Athïr, al-Kämil fì'l-tārïkh, vol. 1, pp. 176-81; Ibn Kathīr, Qișaș alanbiy $\bar{a}^{2}$, pp. $436-40$.

93 See endnote 41 above.

$94 \mathrm{Tha}^{\mathrm{c}} \mathrm{labī},{ }^{\mathrm{C}} \mathrm{Ara} \bar{a}^{3}$ is al-majālis, pp. 297-302. This story occurs in a variety of other sources. See for instance a Persian version translated in Meisami, The Sea of Precious Virtues, pp. 314-16, and a similar episode in Ginzberg's Legends of the Jews, vol. 4, pp. 175-6.

95 Tha'labī, 'Arā'is al-majälis, p. 324, reports that the women said, 'in kāna Sulaymān qad dhahaba 'aqluhu wa-asă'a a ahkamuhu fa-laysa lanā șabrun 'alā dhālika' (in Ṭabañ, Tārīkh alumam wa'l-mulük, vol. 1, p. 295, citing Suddī, a similar statement is made by the Israelites, 'in kāna Sulaymān fa-qad dhahaba 'aqluhu wa-ankarnā aḥkamahu'). Cf. also Țabarī, Tārīkh alumam wa'l-mulük, vol. 1, p. 294, citing Wahb b. Munabbih; Ibn 'Asākir, Tārīkh madīnat Dimashq, vol. 22, p. 249, citing Sa ${ }^{\circ} \bar{i} d$ b. al-Musayyib; Ibn al-Athīr, al-Kämil fì'l-tārīkh, p. 184. The women here tend to represent the arbiters of Solomon's private life, while the Israelites pass comment on the public. They nonetheless play a very real role in the denunciation of the demon.

96 Tabarī, Tārīkh al-umam wa'l-mulük, vol. 1, p. 294, citing Wahb b. Munabbih, p. 295, citing Suddī; Tha ${ }^{\mathrm{C}}$ labī, ' ${ }^{\mathrm{A}} \overline{\bar{a}}^{ }$is al-majālis, p. 323; Ibn 'Asākir, Tārīkh madīnat Dimashq, vol. 22, pp. 245-6, citing Wahb b. Munabbih; Kisā̄ī, Qișaș al-anbiya $\tilde{a}^{3}$, vol. 2, pp. 293-4; Ibn al-Athīr, al-Kämil fì'l-tārīkh, p. 184.

97 'Umāra b. Wathīma, Kitāb Bad' al-khalq, pp. 134-5; Tha' ${ }^{\circ}$ labī, 'Arä’is al-majālis, p. 297; Ibn 'Asākir, Tārīkh madīnat Dimashq, vol. 22, pp. 245-6, citing Wahb; Ibn Kathïr, Qișaṣ alanbiy $\bar{a}^{3}$, p. 433.

98 See Tha ${ }^{c}$ labī, ${ }^{c}$ Arāis al-majālis, p. 290, citing Abū Hurayra; Ibn ${ }^{\circ}$ Asākir, Tārīkh madīnat Dimashq, vol. 22, p. 235, citing Abū Hurayra.

99 See Kisā̄ ${ }^{\circ}$, Qișaș al-anbiya ${ }^{0}$, vol. 2, p. 273. 
Copyright of Journal of Qur'anic Studies is the property of Edinburgh University Press and its content may not be copied or emailed to multiple sites or posted to a listserv without the copyright holder's express written permission. However, users may print, download, or email articles for individual use. 